\title{
SIMULASI SISTEM PENDETEKSI UNTUK PERALATAN ELEKTRONIK DI RUMAH MELALUI SMS( Short Messages Service)
}

\author{
Oleh: \\ Laxsmy Devy \\ Jurusan Teknik Elektro Politeknik Negeri Padang
}

\begin{abstract}
Simulation of detection system for equipments electronics aim to facilitate people watch existence of equipments electronics or other valuable objects that still residing in on position which determined, if house in a state of remained house owner. This detection also at the same time can be functioned as preventative of thief. This detection system use 2 of HP ( Handphone), HP1 reside in house which incircuit with detection system and HP2 holded by house owner. Existence of electronics equipments that residing in house can be watched automatically from long distance with delivering SMS from HP1 to HP2 on the happening of condition of electronic equipments making of move from initialy position, also alarm will sound at home for notification to security or neighbour. SMS can be also delivered from HP2 to HP1 for the checking of electronic equipments if notification of HP2 at home don't be executed when position the electronic equipments have making a move.

The detection in the form of censor infra red (optocoupler) residing in at elbow equipments of electronic at home which input to parallel port (DB25) of PC (personal of computer). While HP1 incircuit serially port (DB9) and thsi function of HP is executed by program of Visual Basic 6.0. Program to detect infra red and activate alarm also use Visually Basic 6.0.
\end{abstract}

Key Word: Detection, optocoupler, handphone, visual basic 6.0

\section{PENDAHULUAN}

Sistem keamanan kebanyakan digunakan di lembaga pemerintah/swasta dan rumah-rumah mewah. Pada umumnya menggunakan unit security (satpam) atau sistem yang mahal serta belum banyak yang bisa diakses dari jarak jauh. Sistem-sistem yang sudah ada tersebut umumnya untuk keamanan gedung dan bukan untuk masing-masing benda yang berada di ruangan.
Sistem serupa, yaitu kendali jarak jauh menggunakan SMS ini telah di publikasikan oleh Jazi Eko Isyanto dan Eko Purwadi ( Universitas Gajah Mada) mereka mengaplikasikan system control ini untuk alat pemantau suhu jarak jauh, mereka menggunakan microcontroller AVR oleh Jazi Eko Isyanto dan Eko Purwadi ( Universitas Gajah Mada) mereka mengaplikasikan system control ini untuk alat pemantau suhu jarak jauh, mereka menggunakan microcontroller AVR AT90S2313 dan menggunakan HP 
siemens A50. Persamaan sistem yang kami buat ini dengan sistem yang di buat oleh Jazi dan Eko adalah sama - sama menggunakan SMS untuk memberikan informasi ke client. Sedangkan perbedaannya adalah pada sistem yang kami buat ini menggunakan bahasa pemrograman Visual basic dan menggunakan hp Nokia 5110 yang mendukung Dinamic Link Library dan berguna untuk mengubah data PDU ke bahasa yang kita kenali dan juga mereka menggunakan sensor suhu sedangkan kami menggunakan sensor infra merah. ( jazi@ugm.ac.id ). Firman Prima Djauhari dari ITB juga membuat sistem dengan menggunakan SMS dan mengaplikasikannya sebagai alternatif otentikasi transaksi di Internet untuk mencegah penggunaan curian nomor kartu kredit.

Mastarizal dari Universitas Indonesia juga membuat alat yang dapat memonitoring peralatan listrik di rumah tangga menggunakan Handphone. Mastarizal ini menggunakan microcontroller AT90S8535 sebagai pengendalinya dan menggunakan $\mathrm{Hp}$ siemens C35i sebagai Hp server. Mastarizal harus menggunakan ATcommand sebagai perintah untuk mengirim dan menerima SMS sehingga pada programnya banyak menggunakan memoridarimicrocontrollertersebut. ( ${ }^{\mathrm{a}} \mathrm{mar}$ ta@ui.edu).

Adapun tujuan sistem pendeteksi peralatan elektronik atau benda-benda lainnya di rumah dirancang, adalah untuk membantu dan memudahkan manusia dalam mengawasi harta bendanya di rumah saat dia berada di luar rumah atau dapat juga sebagai anti maling. Dengan memanfaatkan telpon selular yang dapat dibawa kemanapun, kita dapat mengetahui keadaan rumah pada umumnya dan benda berharga atau peralatan elektronik khususnya. Dengan sistem pendeteksi ini kita juga dapat mengetahui selain orang di luar rumah juga orang di dalam rumah itu sendiri yang memindahkan benda atau peralatan elektronik yang kita deteksi.

Pembahasan pada tulisan ini antara lain : Hp yang digunakan untuk pendeteksi keberadaan peralatan elektronik ini adalah Hp Nokia 5110 yang bisa mengirimkan sms atau informasi ke HP client yang berbeda jenis, sensor yang digunakan adalah sensor infra red dan dapat di jadikan sebagai input untuk paralel port, bahasa pemrograman yang kami gunakan adalah Visual basic dapat diaplikasikan untuk pendeteksi keberadaan peralatan elektronik serta posisi HP tentu saja harus dalam area jangkauan frekuensi selullar yang digunakan.

Komputer adalah suatu alat elektronika untk mengolah data dengan menggunakan suatu program tertentu untuk menghasilkan informasi. Fungsi komputer disamping untuk menyimpan data, mengolah data, media komunikasi data juga dapat digunakan sebagai pengontrol suatu alat (peripheral device).

Sistem komputer dalam pengoperasiannya pada IBM PC dan komputer -komputer yang kompatibel dapat dibedakan 3 kategori utama yaitu: Perangkat keras (Hardware) adalah komponen yang secara fisik dapat dilihat dan disentuh. Secara garis besar hardware sebuah komputer dibagi lagi menjadi 3 bagian ; Unit CPU, (ni, Control unit, Main memory, Aritmatic and logical unit), Input Device (keyboard, mouse, microphone, sensor, scanner, camera), Output Device, (printer, display monitor, load sound/speaker), Memory dan Secondary storage. Pada gambar dibawah ini dapat dilihat organisasi sebuah komputer secara umum [(Zaks, 1991), terjemahan]. 


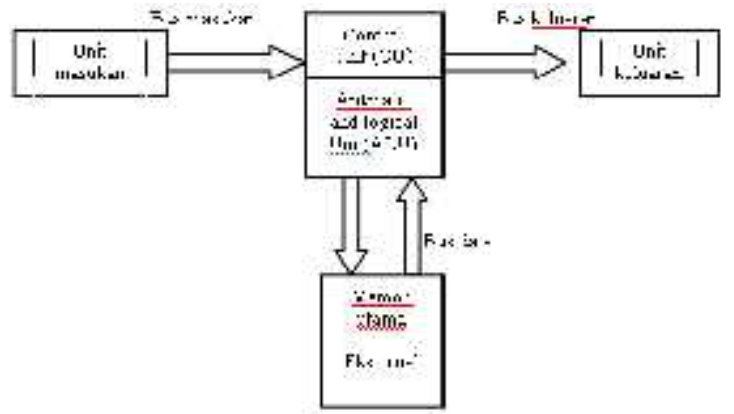

Untuk komputer PC pada umumnya mempunyai port komunikasi, yang merupakan penghubung antara komputer dengan dunia luar. Rangkaian penghubung antar komputer dengan peripheral yang berada diluar komputer ini disebut dengan interface. Interface berdasarkan sistem penyaluran data, terbagi atas dua jenis yaitu : penyaluran data secara parallel, penyaluran data secara serial. Perangkat lunak (Software) adalah suatu program yang dipakai untuk keperluan pengoperasian komputer ataupun untuk menjalankan hardware, diantaranya Operating System (OS), Application softwaredan program aplikasi. Operator (Brainware) adalah orang yang menangani atau menjalankan sistem komputer. Adapun tingkatannya adalah : Operator, Programmer dan System analis.

Konsep Dasar Interface atau antar muka adalah rangkaian yang bertugas menyesuaikan kerja dari piranti peripheral yang sesuai dengan cara kerja komputer itu sendiri. Rangkaian diperlukan karena besarnya (tegangan, arus, daya dan kecepatan proses) piranti peripheral kebanyakan tidak sesuai dengan peripheral $\mathrm{I} / \mathrm{O}$ device, maka harus disesuaikan dengan bantuan interface. Untuk menghubungkan peripheral seperti Relay, Motor, Sensor, Catu daya, IC, dan lain-lain ini perlu interface. Pengertian interface sendiri adalah rangkaian elektronik yang digunakan untuk menghubungkan antara dua sistem, agar sistem tersebut bisa berkomunikasi atau proses handshaking.
Konsep Dasar Paralel Port menurut (Dwi Sutadi, 2003), arsitektur komputer personal ( personal computer, PC) pada umumnya memiliki port paralel, yang mana port paralel ini berfungsi sebagai interface atau sebagai jalur penghubung komunikasi data dari perangkat di dalam komputer dengan peralatan di luar komputer. Umumnya port paralel yang ada pada komputer merupakan fasilitas untuk penggunaan printer, oleh sebab itulah port ini juga disebut port printer (Line Printer, LPT). Sedangkan konektor paralel port yang sering digunakan adalah DB-25, dari 25 pin yang ada pada konektor DB-25 tersebut, hanya 17 pin yang digunakan untuk saluran pembawa informasi dan yang berfungsi sebagai ground ada 8 pin. Namun dengan bantuan program aplikasi yang ada kita dapat memanfaatkan port ini sebagai sarana pengendali sederhana dengan menggunakan pin-pin yang mengantarkan sinyal data.

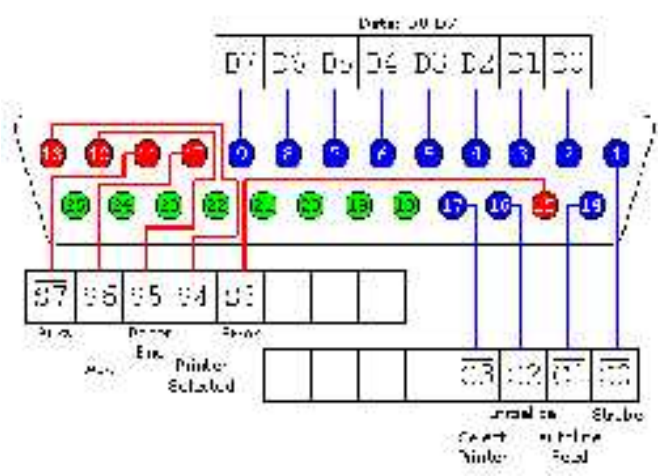

Gambar : konfigurasi pin-pin port paralel.

Port Serial, menurut (Retna Prasetia dan Catur Edi widodo tahun 2004) dikenal dua cara komunikasi data secara serial, yaitu komunikasi serial data secara sinkron dan komunikasi data secara asinkron. Pada komunikasi data serial sinkron, clock dikirimkan bersamasama dengan data serial, sedangkan komunikasi serial data asinkron, clock tidak dikirimkan bersama data serial, 
tetapi di bangkitkan seecara sendirisendiri baik pada sisi pengirim (Transmitter) maupun pada sisi penerima (Receiver). Pada IBM PC kompatibel port serialnya termasuk jenis asinkron. Komunikasi data serial ini dikerjakan oleh UART ( Universal Asyncronous Receiver/Transmiter). IC UART di buat kusus untuk mengubah data paralel menjadi data serial dan memenerima data serial yang kemudian di ubah kembali menjadi data paralel. Pada UART, kecepatan pengiriman data (Baud Rate) fase clock pada sisi transmitter dan pada sisi receiver harus sinkron. Untuk itu di perlukan sinkronisasi antara transmitter dan receiver. Hal ini dilakukan oleh bit "Start" dan bit "Stop". Ketika saluran transmisi dalam keadaan idle output UART adalah dalaam keadaan logika "1". Ketika transmitter ingin mengirimkan data, output UART akan diset terlebih dahulu kelogika "0" untuk waktu satu bit. Sinyal ini pada receiver akan dikenali sebagai sinyal "start" yang di gunakan untuk mengsinkronkan fase clocknya sehingga sinkron dengan fase clock transmitter. Selanjutnya ,clock akan di kirimkan secara serial dari bit paling rendah (bit0) sampai bit tertinggi. Selanjutnya akan di kirim sinyal stop sebagai akhir dari pengiriman data serial. Standar sinyal komunikasi serial yang banyak di gunakan adalah standart RS 232 yang di kembangkan oleh Electronic Industry Association (EIA). Yang pertama kali dipuplikasikan pada tahun 1992. Standar sinyal serial RS 232 memiliki ketentuan level tegangan sebagai berikut : Logika "1" disebut mark terletak antara $-3 \mathrm{~V}$ hingga -25 Volt, logika "0" disebut Space tereletak antara $+3 \mathrm{~V}$ hingga $+25 \mathrm{~V}$, daerah tegangan antara -3 Volt hingga +3 Volt adalah invalid level, yaitu daerah tegangan yang tidak memiliki level logika pasti sehingga harus di hindari. Demikian juga, level tegangan lebih negative dari -25 Volt atau lebih positif dari +25 Volt juga harus di hindari karena tegangan tersebut dapat merusak line driver pada saluran RS232.

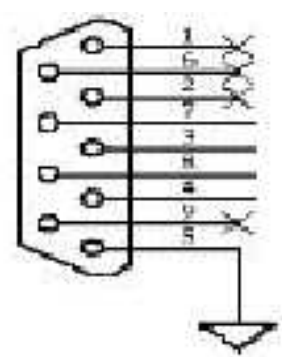

Gambar : serial port dengan pin-pinnya.

\section{Bahasa Pemrograman}

Pendeteksi pencurian melalui sms ini menggunakan bahasa pemrograman Visual basic.Visual basic 6.0 adalah salah satu bahasa pemrograman untuk membuat aplikasi dalam lingkungan windows. Visual basic yang sering disingkat dengan VB merupakan bahasa pemrograman yang dalam pengembangannya menggunakan pendekatan visual (GUI - Graphical User Interface) untuk merancang antarmuka ( interface ). Dalam lingkungan MS Windows, antarmuka pengguna (user interface) penting sekali peranannya, karena dalam program aplikasi yang kita buat pengguna senantiasa berinteraksi dengan user interface tanpa sadar bahwa di belakangnya berjalan instruksi - instruksi program yang menjalankan aplikasi tersebut. Beberapa point yang penting dalam sejarah perkembangan VB : Visual basic pertama kali dikeluarkan pada tahun 1991, yaitu program visual Basic untuk DOS dan untuk windows, Visual Basic 3.0 dirilis pada tahun 1993, Visual Basic 4.0 dirilis pada tahun 1994 dengan tambahan dukungan untuk aplikasi 32 bit, Visual Basic 6.0 dirilis pada akhir tahun 1998. Visual Basic versi terakhir yaitu Visual Basic .NET dirilis pada tahun 2002.

Kelebihan pemrograman Visual Basic ini adalah : pemrograman berbatas 
visual /grafik (GUI) sehingga pembuatan program aplikasi menjadi lebih mudah dan nyaman. Pembuatan dan penempatan antarmuka (Interface) hanya dengan membangun objek di layar monitor, tanpa harus menuliskan kode program yang panjang dan rumit. Basis bahasa pemrograman menggunakan BASIC (Beginners All-Purpose Symbolic Intruction Code), yakni salah satu bahasa pemrograman yang cukup sederhana dan mudah di pelajari. Visual Basic menyediakan perangkat yang dapat di gunakan untuk membuat program aplikasi baik aplikasi kecil dan sederhana untuk keperluan sendiri, hingga aplikasi untuk sistem enterprise yang besar dan rumit, atau bahkan aplikasi yang di jalankan melalui internet. Visual basic memiliki ruang kerja ( workspace) yang terpadu untuk membuat program aplikasi. Ruang kerja terpadu ini di sebut dengan IDE ( Integrated Development Environment). Gambar berikut menunjukkan ruang kerja Visual Basic 6.0 .

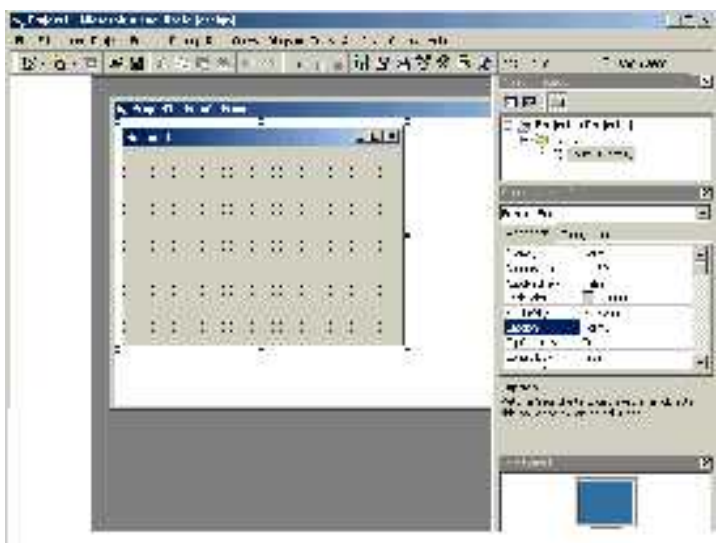

Gambar : Ruang kerja Visual basic 6.0 dengan jendela - jendela yang terbuka.

Di dalam ruang kerja tersebut terdapat :

Menu Bar: berisi menu - menu utama visual basic 6.0. misalnya menu untuk mengolah file, menu pengeditan, menu untuk mengatur tampilan dan lain - lain. Di dalam menu - menu tersebut terdapat sub-submenu. Main Toolbar: berisi icon - icon untuk menjalankan suatu perintah/tugas secara cepat. Project Explorer Window: jendela untuk menampilkan daftar form dan modul projek yang sedang di buat. Proyek merupakan kumpulan dari modul form, modul class, file yang membangun program aplikasi. Properties Window: berisi daftar untuk ( men-setting) properti objek yang sedang aktif. Kotak pada bagian atas berisi semua objek yang ada. Ada dua pilihan tampilan yaitu: Alphabetic ( urut abjad) dan catagorized ( urut berdasarkan objek ). Form Layout
Window: jendela yang menunjukkan posisi relatif form terhadap layar monitor. Form Designer: jendela untuk merancang aplikasi yang sedang di buat. Code Editor Window: merupakan tempat untuk menuliskan coding

Salah satu Jendela yang sangat penting dan akan paling sering dipakai pada saat merancang user Interface yaitu Tool Box..di dalam tool box terdapat berbagai macam kontrol/komponen yang dapat di tanamkan pada form untuk membentuk user interface. Fungsi dari masing - masing intrinsik kontrol tersebut adalah : Pointer bukan merupakan objek kontrol, digunakan untuk memilih kontrol yang sudah ada di dalam form. PictureBox adalah objek kontrol yang di gunakan untuk menampilkan gambar (image) dengan format BMP.ICO (icon), WMF 
(metafile), GIF, JPEG, DIB (Bitmap), CUR (cursor), dan EMF (enhanced metafile).

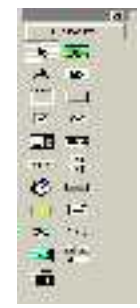

Gambar : Tool Box visual basic 6.0 dengan semua kontrol standar

Label adalah objek kontrol yang digunakan untuk menampilkan teks yang tetap dan tidak dapat diubah oleh pemakai (user). TextBox adalah objek kontrol yang digunakan untuk menampung kata (string) yang di masukkan oleh pemakai. TextBox dapat menampung satu baris maupun banyak baris. Frame adalah kontrol yang berfungsi untuk menampung kontrol kontrol lainnya dalam suatu kelompok. CommandButton adalah kontrol tombol perintah yang berfungsi untuk membangkitkan kejadian (event) tertentu ketika user melakukan klik padanya. CheckBox digunakan untuk memasukkan pilihan yang isinya ya/tidak, yes/no, benar/salah, atau true/false. OptionButton adalah kontrol untuk memasukkan pilihan yang memungkinkan user memilih lebih dari satu pilihan. ListBox adalah kontrol untuk menampung sejumlah item dan user dapat memilih lebih dari satu (bergantung pada property multy select) ComboBox adalah kombinasi dari textboxdan listbox dimana pemasukan data dapat dilakukan dengan pemilihan atau pengetikan langsung. HscrollBar dan VscrollBar digunakan untuk membentuk scroll yang berdiri sendiri. Timer adalah kontrol waktu yang berfungsi untuk proses background yang diaktifkan berdasarkan interval waktu tertentu. Kontrol ini nonvisual dan tidak terlihat oleh user. DriveListBox, DirLIstbox, dan FileListBox digunakan untukmembuat kotak dialog yang berkaitan dengan file/folder. Shape dan Line digunakan untuk membuat bentuk seperti garis, persegi, bulatan, oval, dan lain - lain. Image fungsinya menyerupai PictureBox namun tidak dapat di gunakan untuk menampung kontrol lainnya. Kontrol image menggunakan sumberdaya (resource) yang lebih kecil daripada PictureBox. Data digunakan untuk pengaksesan database. OLE (Object Lingking and Embedding) berfungsi untuk menjalankan program aplikasi window yang lain ke dalam program aplikasi yang kita buat. (Isroi dan Arief Ramadhan. 2004)

Optocoupler 4N25 adalah suatu komponen LED dan transistor foto yang terintegrasi pada satu chip. Pada perancangan ini penulis menggunakan Optocoupler 4N25.

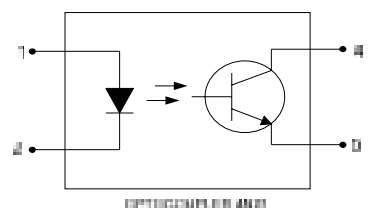

\section{Gambar . Konfigurasi Optocoupler $4 \mathrm{~N} 25$.}

Pemilihan Optocoupler 4N25 didasarkan atas beberapa keuntungan antara lain : Kecepatan operasi lebih tinggi, Kompatibel dengan rangkaianrangkaian logika, respon frekuensi sampai $100 \mathrm{KHz}$. Optocopler (disebut juga optoisolator atau isolator yang tergandeng optik) menggabungkan LED dan fotodioda dalam satu kemasan. Optocoupler mempunyai LED pada sisi masukan dan fotodioda pada sisi keluaran . Tegangan sumber $1 \mathrm{~V}$ dan tahanan seri R1 menghasilkan arus melalui LED. Sebagai gantinya cahaya dari LED mengenai fotodioda, dan ini menyebabkan timbulnya arus balik $\mathrm{I}_{2}$. Dengan menambahkan tegangan tegangan - tegangan melingkari simpul keluaran., diperoleh: 


$$
\begin{aligned}
& \mathrm{V}_{\text {out }}-\mathrm{V}_{2}+\mathrm{I}_{2} \mathrm{R}_{2}=0 \quad \text { atau } \\
& \mathrm{V}_{\text {out }}=\mathrm{V}_{2}-\mathrm{I}_{2} \mathrm{R}_{2}
\end{aligned}
$$

Tegangan keluaran tergantung pada arus balik $\mathrm{I}_{2}$. Bila tegangan masuk $\mathrm{V}_{1}$ berubah, jumlah cahayanya juga berubah. Ini berarti bahwa tegangan keluar berubah sejalan dengan tegangan masuk. Itulah sebabnya mengapa gabungan LED dan fotodioda disebut optocoupler, alat yang dapat menggandeng simpal masuk ke rangkaian keluar. Keuntungan utama optocoupler ialah pemisahan secara listrik antara rangkaian masuk dan rangkaian keluarnya. Dengan optocoupler, hubungan yang ada antara masukan dan keluaran hanya seberkas cahaya. Karena hal ini kita dapat memperoleh resistansi penyekatan diantara dua rangkaian itu dalam ribuan megaohm. Pemisahan seperti ini kebetulan dibutuhkan dalam pemakaian pemakaian bertegangan tinggi yang potensial diantara dua rangkaian itu dapat berbeda sampai beberapa ribu volt.(Drs. Ganti Depari, Mpd)

\section{METODE PENELITIAN}

Diagram blok menggambarkan secara umum bagaimana cara kerja rangkaian secara keseluruhan. Diagram blok system alat pendeteksi pencurian peralatan elektronik melalui SMS menggunakan aplikasi pemrograman visual basic 6.0 terbagi menjadi beberapa bagian blok penting, yaitu :

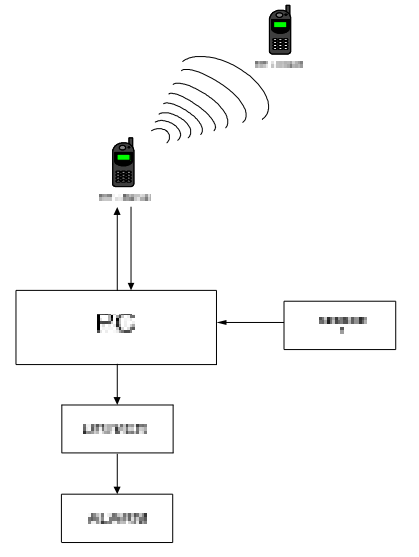

Perancangan Hardware, alat pendeteksi pencurian ini merupakan suatu alat yang terdiri dari komponen elektronika yang dihubungkan dengan komputer melalui port paralel dengan menggunakan konektor DB 25 dan inputnya diperoleh dari modul program, alat ini dirancang untuk membantu orang - orang yang sibuk beraktifitas di luar rumah dan juga membantu pekerjaan satpam. Sistem pendeteksi peralatan elektronik ini akan bekerja apabila sensor aktif ( benda diambil ) bersamaan dengan ini alarm aktif setelah beberapa detik alarm akan mati sendiri karena telah ada timernya. Kemudian parallel port akan melakukan proses pembandingan data dan jika sesuai maka parallel port akan melakukan komunikasi dengan serial port dimana HP-Server terhubung pada parallel port akan mengirimkan sms ke HP-Client. Rangkaian hardware sistem ini dibuat berdasarkan penentuan spesifikasi sistem dari rangakaian keseluruhan sehingga menghasilkan input dan ouput yang diinginkan sistem. Perancangan hardware meliputi perancangan blok diagram sensor infrared, rangkaian driver alarm, rangkaian parallel port dan rangkaian power supply.

Pembuatan Rangkaian Sensor Infrared, adalah rangkaian untuk menyensor benda yang dipasang pada suatu ruangan, dimana jika kondisi awal terhalang benda maka pada output akan logika " 0 " dan jika benda terangkat atau benda tidak ada maka output akan logika 1, logika ini yang merupakan input (masukan) bagi parallel port. Rangkaian dari sensor ini dapat dilihat pada gambar dibawah ini : 


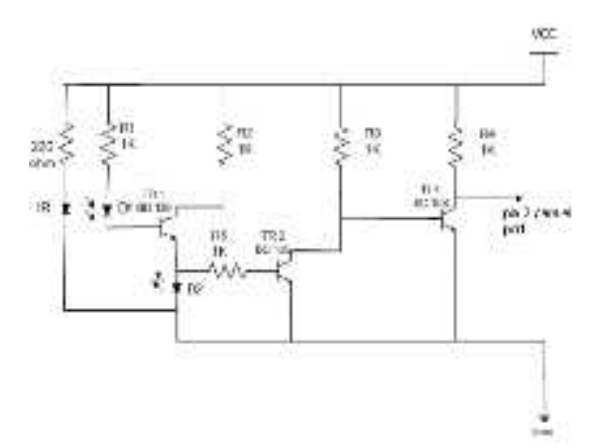

Gambar : Rangkaian Sensor Infra Red.

\section{Pembuatan Rangkaian Driver}

Alarm ini adalah rangkaian yang berfungsi untuk mengaktifkan sebuah alarm, dimana alarm ini adalah output dari paralel port. Alarm yang digunakan disini adalah alarm $12 \mathrm{~V} \mathrm{DC}$, alarm akan aktif jika transistor mendapat arus bias $0,18 \mathrm{~mA}$, aktifnya alarm bersamaan dengan aktifnya sensor, jadi jika sensor aktif alarm berbunyi. Rangkaian Driver alarm ini dapat dilihat pada gambar dibawah ini :

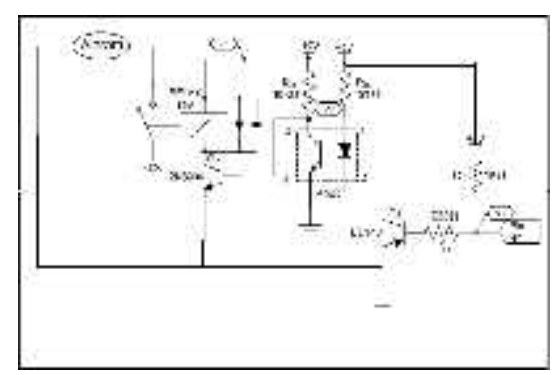

Gambar : Rangkaian Driver Alarm.

\section{Pembuatan Rangkaian Catu}

Daya yang digunakan, berguna untuk memberikan daya yang cukup sehungga seluruh rangkaian dapat melaksanakan fungsinya dengan baik. Pada rangkaian catudaya ini penurun tegangan yang digunakan adalah transformator step down. Transformator ini berfungsi untuk menurunkan tegangan AC $220 \mathrm{~V}$ menjadi tegangan $\mathrm{AC} 12 \mathrm{~V}$ dan $\mathrm{AC} 6 \mathrm{~V}$. dimana trafo yang digunakan adalah Trafo CT 1A. Sehingga tegangan output trafo menghasilkan tegangan $0 \mathrm{~V}-5 \mathrm{~V}$ dengan menggunakan regulator $5 \mathrm{~V}$ (7805). Penyearah yang digunakan adalah dioda silikon sebagai penyearah gelombang penuh yang merubah bentuk gelombang AC menjadi gelombang DC. Dioda yang digunakan yaitu dioda silikon dengan arus yang digunakan 6A, agar tidak bekerja terlalu berat. Output dioda ini telah menjadi gelombang searah tetapi bentuk gelombang tersebut masih dalam keadaan cacat (tidak murni). Filter yang digunakan adalah kapasitor elektrolit . kapasitor ini berfungsi untuk menyaring (memfilter) output dari dioda jembatan sehingga output filter menghasilkan bentuk gelombang searah yang rata (tidak cacat) dengan output tegangang $5 \mathrm{~V}$ DC. Kapasitor ini bernilai 4700 $\mathrm{uF} / 50 \mathrm{~V}$ dan $2200 \mathrm{uF} / 50 \mathrm{~V}$. Regulator yang digunakan adalah IC yang berfungsi untuk menstabilkan tegangan agar tidak naik turun kerangkaian dari output filter dengan tegangan 5V DC. Komponen yang digunakan adalah type LM 7805 dan LM 7812. Rangkaian catu daya dapat dilihat dibawah ini :

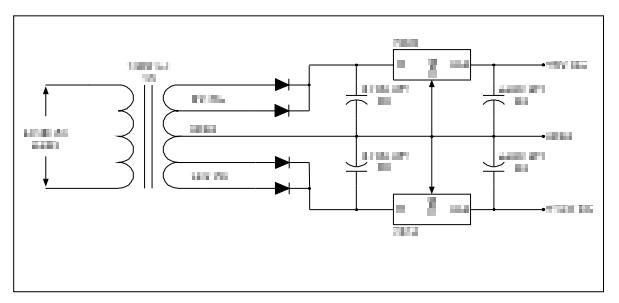

Gambar : Rangkaian Power Supply.

\section{HASIL DAN PEMBAHASAN}

Pengujian Hardware dilakukan setelah pekerjaan assembling selesai dan dilaksanakan pada tiap-tiap blok. Pada pengujian ini perlu dilakukan pengukuran pada sensor sebagai input. Sebelum melakukan pengukuran kita harus menyiapkan terlebih dahulu alatalat yang mendukung didalam melakukan pengukuran. Adapun peralatan-peralatan yang mendukung didalam pengukuran tersebut adalah : Multimeter Digital dan Multimeter analog. Pengujian Catu Daya akan 
menghasilkan tegangan output sebesar $12 \mathrm{~V}$ dan $5 \mathrm{~V}$. tegangan $12 \mathrm{~V}$ digunakan pada rangkaian driver alarm. Tegangan $5 \mathrm{~V}$ digunakan untuk rangkaian sensor infra red. Tegangan sekunder 12VAC dan 6VAC diperoleh dari tegangan jalajala PLN yang diturunkan oleh trafo stepdown, kemudian tegangan ini dihubungkan lagi kerangkaian dioda dan diteruskan ke filter yaitu kapasitor untuk menghasilkan tegangan searah 12VDC dan 5VDC. Tegangan 5VDC berasal dari tegangan $12 \mathrm{VAC}$ yang distabilkan lewat regulator tegangan yaitu LM 7805, dan tegangan 12VDC yang distabilkan lewat regulator tegangan yaitu LM 7812 . Pengujian Rangkaian Infra Red ini terdiri dari Foto dioda, Infra Red. Rangkaian sensor ini berguna untuk mendeteksi ada tidaknya benda yang disensor. Adapun pengukuran yang kami lakukan menghasilkan data sebagai berikut :

\begin{tabular}{|l|l|}
\hline Kondisi & $\mathrm{V}$ \\
\hline $\begin{array}{l}\text { ON ( Tidak Ada } \\
\text { Benda) }\end{array}$ & 4,92 \\
\hline OFF ( Ada Benda ) & 0,02 \\
\hline
\end{tabular}

\section{Pengujian Rangkaian Driver Alarm}

Ini terdiri dari transistor, optocoupler, relay, dioda, kapasitor dan resistor.pada blok driver alarm pengujian dilakukan dengan memberikan logika tinggi, dimana pada pengukuran didapat data sebagai berikut :

\begin{tabular}{||l|l|l|l||}
\hline KONDISI & V1 & V2 & V3 \\
\hline ON (Tidak & 4,91 & 4,58 & 11,97 \\
Ada Benda) & Volt & Volt & Volt \\
\hline OFF ( Ada & 0,22 & 1,24 & 1,33 \\
Benda ) & Volt & Volt & Volt \\
\hline
\end{tabular}

\section{Pembahasan Rangkaian Sensor}

Saat sinar infra red terhalang oleh benda maka $\mathrm{V} 1=0$, sehingga arus pada fotodioda adalah:

$$
\begin{aligned}
& \mathrm{I}=\mathrm{Vcc} / \mathrm{R} \\
& \mathrm{I}=5 \mathrm{~V} / 1 \mathrm{Kohm} \\
& \mathrm{I}=5 \mathrm{~mA}
\end{aligned}
$$

Sedangkan pada transistor BC108 $\mathrm{I}_{\mathrm{C}(\mathrm{SAT})}$ adalah :

$$
\begin{aligned}
& \mathrm{I}_{\mathrm{C}(\mathrm{SAT})}=\frac{V_{C C}-V_{C E}}{R_{C}} \\
& \quad=5 \mathrm{~V}-0,02 / 1 \mathrm{k} \mathrm{ohm} \\
& \quad=4,98 \mathrm{~mA} \\
& \begin{aligned}
\mathrm{Vc} & =\mathrm{Vcc}-\mathrm{Ic} \cdot \mathrm{Rc} \\
& =5 \mathrm{~V}-4,98 \mathrm{~mA} \cdot 1 \mathrm{Kohm} \\
& =5 \mathrm{~V}-4,98 \mathrm{~V} \\
& =0,02 \mathrm{~V}
\end{aligned}
\end{aligned}
$$

maka output pada V1 atau Vin adalah 0,02 volt, sehingga tegangan ini akan menjadi logika "0", sebagai masukan PC. Sedangkan pada saat sinar infra red mengenai basis atau benda diangkat maka V1 = 1 , sehingga arus pada fotodioda adalah:

$$
\begin{aligned}
& \mathrm{I}=\mathrm{Vcc} / \mathrm{R} \\
& \mathrm{I}=5 \mathrm{~V} / 1 \mathrm{Kohm} \\
& \mathrm{I}=5 \mathrm{~mA}
\end{aligned}
$$

Sedangkan pada transistor $\mathrm{BC} 108 \mathrm{I}_{\mathrm{C}(\mathrm{SAT})}$ adalah :

$$
\begin{aligned}
& \mathrm{I}_{\mathrm{C}(\mathrm{SAT})}=\frac{V_{C C}-V_{C E}}{R_{C}} \\
& \quad=5 \mathrm{~V}-4,92 / 1 \mathrm{k} \mathrm{ohm} \\
& \quad=0,08 \mathrm{~mA} \\
& \begin{aligned}
\mathrm{Vc} & =\mathrm{Vcc}-\mathrm{Ic} \cdot \mathrm{Rc} \\
& =5 \mathrm{~V}-0,08 \mathrm{~mA} \cdot 1 \mathrm{Kohm} \\
& =5 \mathrm{~V}-0,08 \mathrm{~V} \\
& =4,92 \mathrm{~V}
\end{aligned}
\end{aligned}
$$

maka output pada V1 atau Vin adalah 4,92 volt, sehingga tegangan ini akan menjadi logika "1", sebagai masukan PC.

\section{Pembahasan Driver Alarm}

Pada driver alarm ini menggunakan transistor sebagai saklar dimana pada jika hitung adalah sebagai berikut :

$$
\begin{aligned}
& \mathrm{I}_{\mathrm{LED}}=\frac{V_{C C}-V_{L E D}}{R_{C}}= \\
& \frac{5 \mathrm{~V}-0,32 \mathrm{~V}}{100 \Omega}=\frac{4,68 \mathrm{~V}}{100 \Omega}=46,8 \\
& \mathrm{~mA} \\
& \mathrm{I}_{\mathrm{C}(\mathrm{SAT})}=\mathrm{I}_{\mathrm{LED}}
\end{aligned}
$$




$$
\begin{aligned}
& \mathrm{I}_{\mathrm{B}}=\frac{V_{I N}-V_{B E}}{R_{B}}= \\
& \frac{5 V-0,7 V}{220 \Omega}=\frac{4,3 V}{220 \Omega}= \\
& 19,54 \mathrm{~mA} \\
& \mathrm{~V}_{\mathrm{IN}}=\mathrm{V} 1 \quad=\mathrm{I}_{\mathrm{B}} \cdot \mathrm{R}_{\mathrm{B}}+ \\
& \mathrm{V}_{\mathrm{BE}} \\
& =19,54 \mathrm{~mA} .220 \Omega+0,7 \mathrm{~V} \\
& =5 \text { Volt }
\end{aligned}
$$

Pembahasan Software, pengujian parallel port dapat di lakukan dengan cara manual maupun secara program. Secara manual kita dapat melakukan dengan memakai multimeter dengan cara mengukur keluaran dari DB 25, apakah ada tegangan atau tidak. Kita juga bisa menceknya melalui program visual basic 6.0 dengan cara mengambil perintah pada tool box yaitu : command 4 buah, text box 1 buah, timer 1 buah

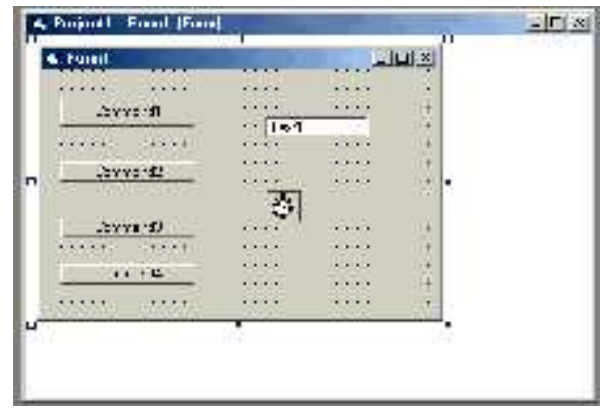

Setelah mengambil perintah - perintah pada tool box lalu menuliskan program pada codingnya. Programnya adalah:

Option Explicit

Dim variabel As Byte

Private Sub Command1_Click()

Port_Out 888, 3

End $\overline{S u b}$

Private Sub Command2_Click()

'variabel $=$ Port_In(889)

'Text1.Text $=$ variabel

Timerl.Enabled $=$ True

End Sub

Private Sub Command3_Click()

End

End Sub

Private Sub Command4_Click()

Port_Out 888, 0

End Sub

Private Sub Form_Load()

Timerl.Enabled $=$ False

End Sub

Private Sub Timer1_Timer()

'normal in sensor $1=0(s 4=111)$

variabel $=$ Port_In(889) variabel $=$ variabel And 255

Text1.Text $=$ variabel

If variabel $=111$ Then

Port Out 888, 2

End If

End Sub

Sedangkan program untuk mengkoneksikan kabel data ke hp adalah

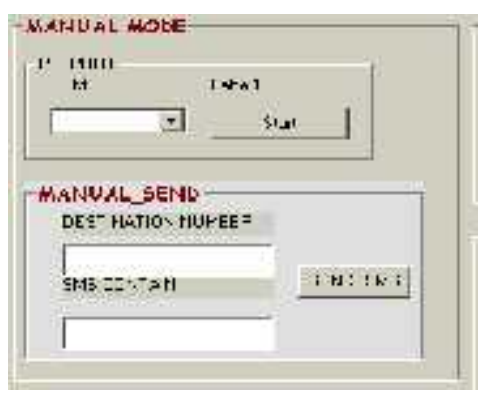

dengan menuliskan programnya pada jendela coding yaitu :

Private Sub Combol_Change()

End Sub

Private Sub Command1_Click()

On Error GoTo ndak muah

NOKIA5110.Connect "COM1" 


\author{
MsgBox "on line" \\ ndak_muah: \\ If $\bar{E} r r<>0$ Then \\ MsgBox "off line", vbOKOnly, "Status \\ Koneksi" \\ End If \\ End Sub \\ Private Sub Command3_Click() \\ NOKIA5110.Connect Combo1.Text \\ If NOKIA5110.Connected Then \\ Labell.Caption = "connected" \\ Else \\ Label1.Caption = "not connected" \\ End If \\ End Sub \\ Private Sub phon_no_Change() \\ End Sub \\ Private Sub Timer1_Timer() \\ alarm1 = Port In(889) \\ 'alarm1 = alarm1 And \&HFO \\ DAT_TERBACA.Text $=$ alarm 1 \\ If alarm $1=127$ Then \\ 'If NOKIA5110.RfLevel $>0$ Then \\ NOKIA5110.SendSMSMessage \\ phon_no.Text, isi_sms.Text \\ 'Tunda 5000 \\ 'MsgBox "SMS sudah terkirim dengan \\ sukses" \\ Label7.Caption = "sending process" \\ Port Out 888, 0 \\ Tunda 10000 \\ Port_Out 888, 1 \\ 'Timer2.Enabled $=$ True \\ Tunda 1000 \\ Port_Out 888, 0 \\ Else \\ Label7.Caption $=$ "can't send sms" \\ 'Tunda 2000 \\ 'MsgBox "hand phone di luar \\ jangkauan" \\ 'End If \\ End If \\ End Sub \\ Private Sub Command4_Click() \\ If NOKIA5110.RfLevel $>0$ Then
}

NOKIA5110.SendSMSMessage

phon_no.Text, isi_sms.Text

'MsgBox "SMS sudah terkirim dengan sukses"

Else

'MsgBox "hand phone di luar jangkauan"

End If

Setelah di buat koneksi ke system dan hp maka kita gabungkan kedua program tersebut pada jendela codingnya (pada lampiran listing program). Setelah di buat programnya maka program itu di RUN dulu, setelah di run jika masih ada kesalahan maka akan langsung ada peringatannya, jika program yang di buat sudah benar maka akan tampil hasilnya.

Cara Pengoperasian Alat, pendeteksi pencurian menggunakan sms dengan aplikasi pemrograman Visual Basic 6.0 ini beroperasi dengan menggunakan sumber tegangan dari rangkaian power supply yang keluarannya adalah $12 \mathrm{~V}$ dan $5 \mathrm{~V}$. Tegangan $12 \mathrm{~V}$ akan digunakan untuk menghidupkan alarm dan tegangan $5 \mathrm{~V}$ untuk sensor.

Pendeteksi keberadaan peralatan elektronik melalui sms dengan aplikasi pemrograman visual basic 6.0 ini akan berfungsi jika tombol on/offnya dionkan. Jika masih ada benda yang menghalangi infra merah maka itu di sebut keadaan normal, jika tidak ada benda yang menghalangi sensor infra merah (Benda diambil) maka sensor akan mengirimkan nilai 1 ke input paralel port, setelah itu PC atau komputer akan mengolah data dengan menggunakan bahasa pemrograman visual basic 6.0. setelah melakukan pembandingan data, jika masukan ke paralel port (pin D0 = 1) maka output dari PC akan keluar ( pin $\mathrm{S} 4=$ 1) berupa perintah untuk membunyikan alarm beberapa saat dan akan mati sendiri karena ada timer yang mengaturnya pemakaian alarm ini berfungsi untuk memberitahukan satpam bahwa telah terjadi pencurian di dalam rumah. Keluaran lain dari PC adalah 
berupa pengiriman sms kepada pemilik rumah yang ada di luar dengan melaui port serial, port serial yang kami gunakan di sini adalah COM1. Adapun bentuk gambar program yang akan menjalankan pendeteksi ini adalah:

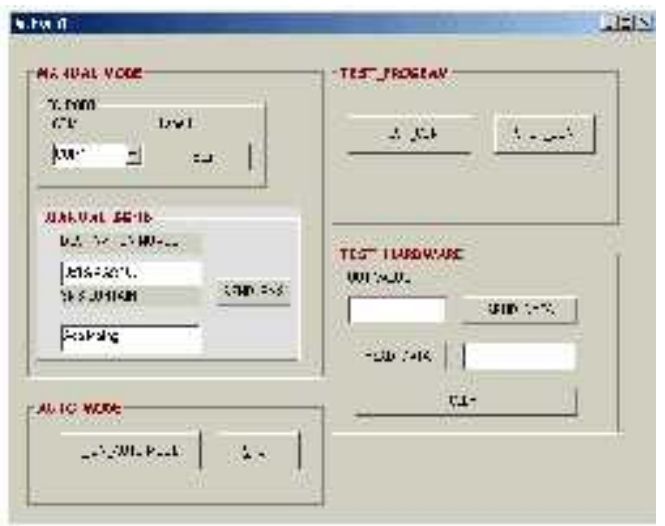

\section{KESIMPULAN DAN SARAN}

Ada beberapa kesimpulan yang dapat diambil dari simulasi pendeteksi peralatan elektronik

1. Pada pembuatan rangkaian sensor, sebaiknya diperhatikan pemilihan tingkat kesensitifannya yang paling baik.

2. Dalam pembuatan kotak pelindung untuk alat ini sebaiknya memilih bahan yang tahan terhadap air, panas, getaran dan lain sebagainya, supaya keamanan alat ini tetap terlindungi dengan baik.

3. Peletakan sistem hendaknya diletakan pada ruangan yang tersembunyi yang tidak bisa dilihat orang

4. Dalam pembuatan driver digunakan optocoupler, karena optocoupler sangat aman digunakan untuk mengontrol beban AC maupun DC. Karena kalau menggunakan transistor dan relay bisa mengakibatkan bouncing.

Untuk pengembangan lebih lanjut disarankan dengan tambahan GPS ( Global Positioning System ) untuk barang - barang yang sangat berharga, maka dapat diketahui letak dari barang yang di curi. Sehingga memudahkan kita untuk menemukannya.

\section{DAFTAR PUSTAKA}

Loveday, G Ceng, MIEE, 1994, "Pengujian Elektronik dan Diagnosa Kesalahan”, Elex Media Komputindo, Jakarta.

Malvino, Albert Paul, 1999, "Prinsipprinsip Elektronika" jilid I, Erlangga, Jakarta

Malvino, Albert Paul, 1999, "Prinsipprinsip Elektronika" jilid II, Erlangga, Jakarta

Petruzella D, Frank, 2001, "Elektronik Industri”. Yogyakarta: Andi, Yogyakarta

Prasetia, Retna dan Catur Edi Widodo, 2004, "Interfacing Port Paralel dan Port Serial komputer dengan Visual basic 6.0", ANDI, Yogyakarta

Surwarto, Edi Aht; Witono, Benny BE; Tarmukan BE, 1982, "Rangkaian Listrik I", PEDC, Bandung,

Surwarto, Edi Aht; Witono, Benny BE; Tarmukan BE, 1983, "Rangkaian Listrik II”, PEDC, Bandung, 
Sutrisno, 1986, "Elektronika Teori dan Penerapannya”, ITB Bandung

Tsutsumi, Kazuo; Moegiharto, Yoedy; Kuswadi, Son; Adil, Ratna, 1982, "Rangkaian Listrik", JICA,

Arif Nopi, Pemrograman Dengan Bahasa

Assambly, www.ilmukomputer.com 
